Kazuyoshi Hirota MD, Noriaki Ohtomo MD, Yoshio Hashimoto MD, Tsuyoshi Kudo MD, Hironori Ishihara MD, Akitomo Matsuki MD

\title{
Midazolam reverses histamine-induced bronchoconstriction in dogs
}

Purpose: Midazolam has been used clinically as a sedative and as an anaesthetic induction agent. However, the bronchodilating effects of midazolam have not been comprehensively evaluated. We sought to determine relaxant effects of midazolam on the airway.

Methods: After our Animal Care Committee approved the study, eight mongrel dogs were anaesthetized with 30 $\mathrm{mg} \cdot \mathrm{kg}$ pentobarbitone $\mathrm{i}$, and were paralysed with $200 \mu \mathrm{g} \cdot \mathrm{kg}^{-1} \cdot \mathrm{hr}^{-1}$ pancuronium. The trachea was intubated with an endotracheal tube (ID $7 \mathrm{~mm}$ ) that had a second lumen for insertion of a superfine fibreoptic bronchoscope (OD 2.2 $\mathrm{mm}$ ) to measure the bronchial cross-sectional area (BCA) continuously. The tip of the bronchoscope was placed at the level of the second or third bronchial bifurcation of the right bronchus. A videoprinter printed the $B C A$ which was then measured with a NIH Image program. Bronchoconstriction was produced with histamine $(H) 10 \mu g \cdot k g$ ' followed by $500 \mu \mathrm{g} \cdot \mathrm{kg}^{-1} \cdot \mathrm{hr}^{-1}$. Thirty minutes later, 0 [saline], $0.01,0.1$ and $1.0 \mathrm{mg} \cdot \mathrm{kg}^{-1}$ midazolam and $25 \mu \mathrm{g}^{\mathrm{kg}} \mathrm{g}^{-1}$ flumazenil were given. The BCA was assessed before (basal area) and $30 \mathrm{~min}$ after the start of $\mathrm{H}$ infusion, and was also measured five minutes after each midazolam and flumazenil iv. At the same time, arterial blood was sampled for plasma catecholamine measurement.

Results: Histamine infusion decreased BCA to $49.7 \pm 17.3 \%$ of basal BCA. More than $0.1 \mathrm{mg} \cdot \mathrm{kg}^{\prime}$ midazolam increased BCA up to $71.7 \pm 15.3 \%$ of the basal $\left(1.0 \mathrm{mg} \cdot \mathrm{kg}^{-1}\right)(P<0.01)$. Plasma adrenaline concentration was decreased from $6.9 \pm 3.8$ to $3.7 \pm 1.9 \mathrm{ng} \cdot \mathrm{ml}^{-1}$ by $1.0 \mathrm{mg} \cdot \mathrm{kg}^{-1}$ midazolam $(P<0.05)$. Flumazenil did not antagonize the relaxant effect of midazolam but reversed the inhibitory effect of midazolam on histamine-induced adrenaline release. Conclusion: Midazolam has a spasmolytic effect on constricted airways but this bronchodilatation was not reversed by flumazenil.

Objectif : En clinique, on utilise le midazolam comme sédatif et comme agent d'induction de l'anesthésie. Cependant, les effets bronchodilatateurs du midazolam n'ont jamais fait l'objet d'une évaluation complète. Nous avons recherché les effets relaxants du midazolam sur les voies aériennes.

Méthodes : Après l'approbation du comité d'expérimentation animale, huit chiens de race commune ont été anesthésiés avec $30 \mathrm{mg} \cdot \mathrm{kg}^{-1}$ de pentobarbital iv et paralysés avec $200 \mu \mathrm{g} \cdot \mathrm{kg}^{-1} \cdot \mathrm{h}^{-1}$ de pancuronium. La trachée a été intubée avec un tube endotrachéal (DI $7 \mathrm{~mm}$ ) avec une deuxième lumière pour l'insertion d'un bronchofibroscope extra-fin (DE $2.2 \mathrm{~mm}$ ) pour la mesure de la surface transversale bronchique (STB) en continu. L'extrémité du bronchoscope a été placée au niveau de la deuxième ou troisième bifurcation de la bronche droite. Une imprimante vidéo imprimait la mesure de la STB avec un programme d'imagerie du NIH. La bronchoconstriction était provoquée avec de l'histamine $(\mathrm{H}) 10 \mu \mathrm{g} \cdot \mathrm{kg}^{-1}$ suivie d'une perfusion de $500 \mu \mathrm{g} \cdot \mathrm{kg}^{\prime} \cdot \mathrm{h}^{\prime}{ }^{\prime}$ Trente minutes plus tard, on administrait $0 \mathrm{mg}, 0,01 \mathrm{mg}, 0.1 \mathrm{mg}$ et $1.0 \mathrm{mg} \cdot \mathrm{kg}^{-1}$ de midazolam et $25 \mu \mathrm{g} \cdot \mathrm{kg}^{-1}$ de flumazénil. La STB était évaluée avant (surface initiale) et $30 \mathrm{~min}$ après le début de la perfusion $\mathrm{H}$ et une autre fois cinq min après chaque injection iv de midazolam et de flumazénil. Au même moment. un échantillon de sang était prélevé pour le titrage des catécholamines.

Résultats : La perfusion d'histamine a réduit la STB de $49 \pm 17,3 \%$ de la valeur initiale. Une dose de plus de $0.1 \mathrm{mg} \cdot \mathrm{kg}^{-1}$ de midazolam augmentait la STB jusqu'à $71,7 \pm 15,3 \%$ de la valeur initiale $\left(1 \mathrm{mg} \cdot \mathrm{kg}^{\prime}, P<0,0\right.$ I) Le midazolam $1.0 \mathrm{mg} \cdot \mathrm{kg}^{-1}$ diminuait la concentration plasmatique d'adrénaline de $6.9 \pm 3,8 \mathrm{a} 3.7 \pm 1,8 \mathrm{ng} \cdot \mathrm{ml}^{-1}$ $(P<0,05)$. Le flumazénil n'a pas inhibé la relaxation produite par le midazolam mais a aboli l'effet inhibiteur du midazolam sur la libération d'adrénaline induite par l'histamine.

Conclusion : Le midazolam a un effet spasmolytique sur la bronchoconstriction mais cet effet n'est pas aboli par le flumazénil.

From the Department of Anesthesiology, University of Hirosaki School of Medicine, Hirosaki 036, Japan.

Address correspondence to: Dr. K. Hirota; Phone: +81-172-33-5111; Fax: +81-172-39-5112.

Accepted for publication July 1, 1997. 
B ENZODIAZEPINES are widely used in clinical practice because of their anxiolytic, muscle relaxant, anticonvulsant and sedative effects. Midazolam is used as an anaesthetic induction agent for critically ill patients in the operating room and for sedation in the Intensive Care Units because it does not have potent depressive cardiovascular effects. ${ }^{1}$ Several in vitro studies indicate that midazolam has a spasmolytic effect on constricted airway smooth muscle. However, in vivo its effect has not been studied. ${ }^{2-4}$

Airway calibre is normally assessed indirectly by measuring airway resistance or compliance, which can be strongly influenced by airway secretions. ${ }^{5}$ However, there are several reports of the relative insensitivity of indirect measurements of airway calibre. ${ }^{6-8}$ We have developed a portable direct method of quantifying bronchial calibre using a superfine fibreoptic bronchoscope. ${ }^{9-11}$ Also, we have shown that the direct visualization method is more specific in the assessment of airway calibre. When assessed by bronchial cross-sectional area (BCA), adrenaline was shown to reverse histamine-induced bronchoconstriction completely, although dynamic pulmonary compliance (Cdyn) and airway resistance (Raw) had not returned to pre-histamine values, although there were correlations between BCA and Cdyn $(\mathrm{r}=0.720, P<0.0001)$ and BCA and Raw $(r=0.727, P<0.0001) .{ }^{11}$

In the present study, BCA was employed to evaluate the in vivo spasmolytic effect of midazolam and the antagonistic effect of flumazenil on histamine-induced bronchoconstriction in dogs.

\section{Methods}

The study protocol was approved by the Animal Care and Use Committee in the University of Hirosaki School of Medicine. Eight mongrel dogs (8-12 kg) were anaesthetized with $30 \mathrm{mg} \cdot \mathrm{kg}^{-1}$ pentobarbitone iv and paralysed by continuous infusion of 200 $\mu \mathrm{g} \cdot \mathrm{kg}^{-1} \cdot \mathrm{hr}^{-1}$ pancuronium. If anaesthesia was not deep enough during experiment, $5 \mathrm{mg} \cdot \mathrm{kg}^{-1}$ pentobarbitone was given although the induction dose could maintain anaesthesia adequately during the experiments. ${ }^{12}$ The tracheas were intubated with endotracheal tubes (ID: $7.0 \mathrm{~mm}$, Univent tube, Fuji System, Tokyo) that had a second lumen usable for a bronchial blocker. The lungs were ventilated with oxygen and the end-tidal $\mathrm{CO}_{2}$ was maintained at $4.0-4.5 \%$. A femoral artery and vein were cannulated to monitor arterial blood pressure and to insert a Swan-Ganz catheter (Baxter Health Co, Tokyo).

\section{Imaging and analysis of airway}

A superfine fibreoptic bronchoscope (OD $2.2 \mathrm{~mm}$ : AF type 22A, Olympus, Tokyo) was inserted through the second lumen of the endotracheal tube placing the tip between the second and third bronchial bifurcation of the right bronchus to monitor continuously the bronchial cross-sectional area (BCA) at the third bifurcation. Previously, we have shown that insertion of the bronchoscope did not change anaesthesia depth as plasma concentrations of noradrenaline and adrenaline were not altered between $30 \mathrm{~min}(138 \pm 45$ and $\left.162 \pm 18 \mathrm{pg} \cdot \mathrm{ml}^{-1}\right)$ and $60 \mathrm{~min}(188 \pm 48$ and $136 \pm$ $18 \mathrm{pg} \cdot \mathrm{ml}^{-1}$, respectively) after bronchoscope insertion. Also, the tip of bronchoscope could be well fixed as BCA did not change during time. ${ }^{9}$ The BCA data after expiration and before inspiration were printed out with a videoprinter (VY-170, Hitachi, Tokyo). Subsequently, analysis of the BCA was performed on a Macintosh computer using the public domain NIH Image program. ${ }^{a}$

\section{Protocol (Figure 1)}

Basal BCA measurements were made prior to beginning histamine administration. Bronchoconstriction was produced by $10 \mu \mathrm{g} \cdot \mathrm{kg}^{-1}$ histamine iv followed by a continuous infusion of $500 \mu \mathrm{g} \cdot \mathrm{kg}^{-1} \cdot \mathrm{hr}^{-1}$ histamine via the pulmonary arterial line of Swan-Ganz catheter until the end of the experiment. In a preliminary study, we found that a stable BCA could be obtained $20-30 \mathrm{~min}$ after the start of the histamine infusion. Systolic blood pressure was maintained $>80 \mathrm{mmHg}$ with fluid (lactate Ringer solution: $50 \mathrm{ml} \cdot \mathrm{kg}^{-1}$ ) and with phenylephrine infusion (initially $0.5-2.0 \mu \mathrm{g} \cdot \mathrm{kg}^{-1} \cdot \mathrm{min}^{-1}$ ) titrated according to systolic blood pressure. Thirty minutes after the start of the histamine infusion, 0 [saline], $0.01,0.1,1.0 \mathrm{mg} \cdot \mathrm{kg}^{-1}$ midazolam and $25 \mu \mathrm{g} \cdot \mathrm{kg}^{-1}$ flumazenil (specific central benzodiazepine antagonist) were given in this order at five minute intervals. The BCA was measured five minutes after each dose of midazolam and flumazenil. The $\mathrm{BCA}$ is presented as $\%$ of basal $\mathrm{BCA}$, respectively: \% $\mathrm{BCA}=($ measured $\mathrm{BCA} \div$ basal BCA) $\times 100$.

Experiments were terminated if: a) airway secretion caused by histamine infusion covered the tip of the bronchoscope and BCA could not be measured, or b) histamine infusion did not decrease BCA by $>30 \%$.

\section{Catecholamines assay}

Arterial blood $(6 \mathrm{ml})$ was collected through the femoral artery simultaneously with BCA measurements to determine plasma adrenaline and noradrenaline concentrations. Blood samples were immediately centrifuged to separate plasma which was then frozen at $-70^{\circ} \mathrm{C}$ until the assay. Plasma concentrations of

\footnotetext{
a Wayne Rasband, US National Institutes of Health, available from Internet by anonymous ftp from zippy. nimh. nih. gov or on floppy disk from NTIS, 5285 Port Royal RD., Springfield, VA 22161, part number PB93-504868).
} 


\begin{tabular}{|c|c|c|c|c|c|c|c|c|c|c|c|}
\hline Drug administration & $\begin{array}{l}\mathrm{H} \text { ir } \\
\Downarrow\end{array}$ & $\begin{array}{c}\text { fusion }(10 \mu \mathrm{g} \\
\text { Saline (M 0 }\end{array}$ & $\begin{array}{l}500 \\
\left.g^{-1}\right)\end{array}$ & $\begin{array}{l}\mu \mathrm{g} \cdot \mathrm{kg}^{-1} \cdot \mathrm{m} \\
\mathrm{M} \mathrm{0.01} \mathrm{n}\end{array}$ & & M $0.1 \mathrm{mg} \cdot \mathrm{kg}^{-1}$ & & M $1.0 \mathrm{mg} \cdot \mathrm{kg}^{-1}$ & & $\begin{array}{c}\text { FLM } 25 \\
\Downarrow\end{array}$ & \\
\hline Time (min) & 0 & 30 & 35 & 40 & 45 & 50 & 55 & 60 & 65 & 70 & 75 \\
\hline $\begin{array}{l}\text { BCA measurement } \\
\text { Catecholamine assay }\end{array}$ & $(+)$ & $\begin{array}{l}(+) \\
(+)\end{array}$ & $\begin{array}{l}(+) \\
(+)\end{array}$ & & $\begin{array}{l}(+) \\
(+)\end{array}$ & & $\begin{array}{l}(+) \\
(+)\end{array}$ & & $\begin{array}{l}(+) \\
(+)\end{array}$ & & $\begin{array}{l}(+) \\
(+)\end{array}$ \\
\hline
\end{tabular}

FIGURE 1 Order of study drug administered. BCA: bronchial cross-sectional area, $\mathrm{H}$ : histamine, $\mathrm{M} 0.01: 0.01 \mathrm{mg} \cdot \mathrm{kg}^{-1} \mathrm{midazolam}$, FLM: $25 \mu \mathrm{g} \cdot \mathrm{kg}^{-1}$ flumazenil.

adrenaline and noradrenaline were determined with gas chromatography mass spectrometry. ${ }^{13}$ The assay coefficient of variation was $8.4 \%$ for adrenaline and $11.3 \%$ for noradrenaline.

\section{Statistical analysis}

All data are expressed as mean $\pm S D$. Data were analysed using repeated measures ANOVA followed by Fisher's protected least significant difference test using Stat View 2.0 on Macintosh computer. $P<0.05$ was considered significant.

\section{Results}

No experiment was terminated by airway secretion and ineffective histamine infusion. Histamine decreased BCA to $49.7 \pm 6.1 \%$ of basal BCA. Doses $>0.1 \mathrm{mg} \cdot \mathrm{kg}^{-1}$ midazolam increased \% BCA $\left(0.1\right.$ and $1.0 \mathrm{mg} \cdot \mathrm{kg}^{-1}$ midazolam: $67.9 \pm 15.3 \%, P<0.01$ and $71.7 \pm 15.3 \%$, $P<0.01$, respectively) (Figure 2 ). Flumazenil did not antagonize midazolam-induced relaxation (Figure 2).

Plasma adrenaline concentration decreased from $6.9 \pm 3.8$ to $3.7 \pm 1.9 \mathrm{ng} \cdot \mathrm{ml}^{-1}(P<0.05)$ after 1.0 $\mathrm{mg} \cdot \mathrm{kg}^{-1}$ midazolam. Flumazenil increased the reduced adrenaline level after midazolam $\left(1.0 \mathrm{mg} \cdot \mathrm{kg}^{-1}\right)$ to $6.3 \pm 2.9 \mathrm{ng} \cdot \mathrm{ml}^{-1}(P<0.05$, Figure 3$)$. Although plasma noradrenaline concentrations changed in a similar direction as those of adrenaline; decrease from $495 \pm 164$ to $412 \pm 208 \mathrm{pg} \cdot \mathrm{ml}^{-1}$ after $1.0 \mathrm{mg} \cdot \mathrm{kg}^{-1}$ midazolam and increase to $488 \pm 244 \mathrm{pg} \cdot \mathrm{ml}^{-1}$ after flumazenil, the changes did not reach statistical significance (Figure 3 ).

\section{Discussion}

In the present study, we found that midazolam (doses $>0.1 \mathrm{mg} \cdot \mathrm{kg}^{-1}$ ) relaxed in vivo histamine-induced bronchoconstriction. Recent studies ${ }^{2-4}$ have also demonstrated that midazolam has bronchodilating effects in vitro. However, the mechanism by which midazolam exerts bronchodilating effects has not been clearly defined. It has been reported that GABA inhibits postganglionic cholinergic neurotransmission ${ }^{15}$ and, thus, the spasmolytic effect might be due to GABA receptor activation by midazolam bound to benzodiazepine

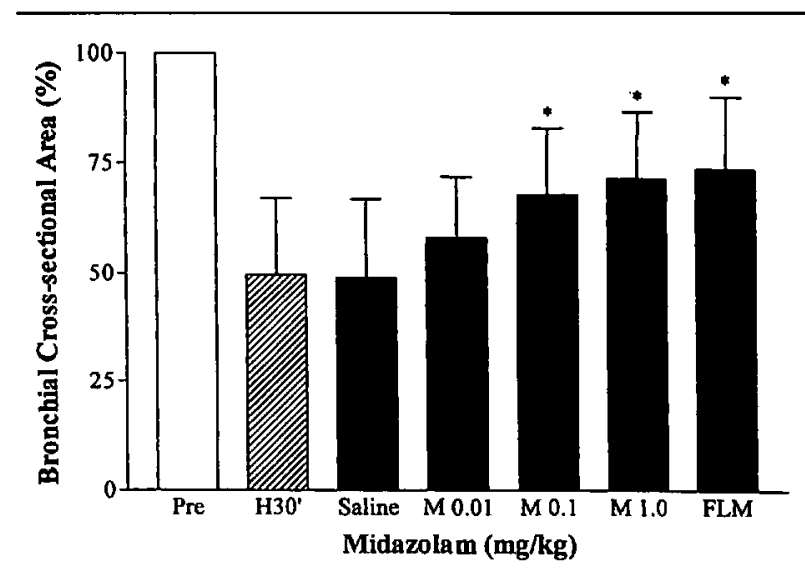

FIGURE 2 Spasmolytic effect of midazolam (M) on histamine (H)-induced bronchoconstriction assessed by changes in bronchial cross-sectional area (BCA).

Pre: before start of $\mathrm{H}$ infusion. $\mathrm{H} 30$ ': 30 min after the start of $\mathrm{H}$ infusion, $M 0.01: 0.01 \mathrm{mg} \cdot \mathrm{kg}^{-1}$ midazolam, FLM $25 \mu \mathrm{g} \cdot \mathrm{kg}^{-1}$ flumazenil, ${ }^{*} P<0.01$ compared with $\mathrm{H} 30$ '. All values are expressed as mean $\pm S D$.

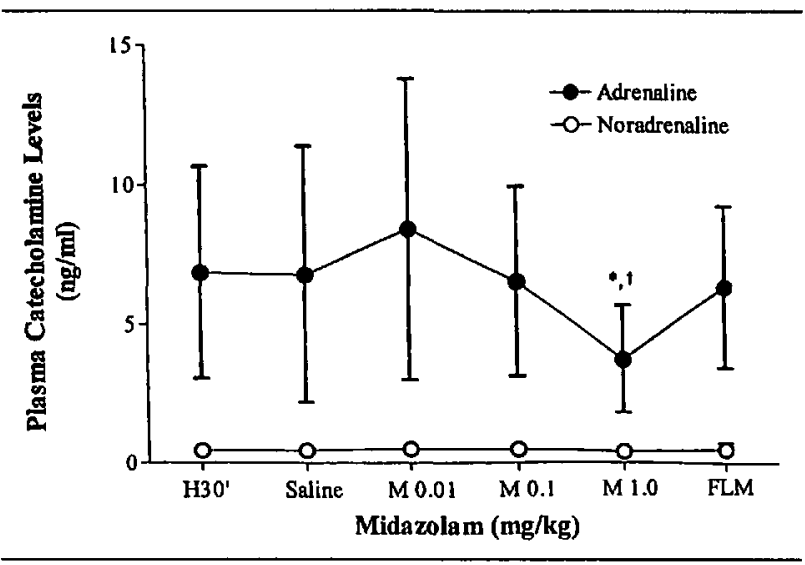

FIGURE 3 Effect of midazolam (M) and flumazenil (FLM) on plasma adrenaline and noradrenaline concentrations.

H30': $30 \mathrm{~min}$ after the start of $\mathrm{H}$ infusion, $\mathrm{M} 0.01: 0.01 \mathrm{mg} \cdot \mathrm{kg}^{-1}$ midazolam, FLM: $25 \mu \mathrm{g} \cdot \mathrm{kg}^{-1}$ flumazenil, ${ }^{\star} P<0.05$ compared with H30', ${ }^{\dagger} P<0.05$ compared with FLM. All values are expressed as mean $\pm S D$. 
binding sites at the GABA receptor. However, we observed that flumazenil, a central benzodiazepine receptor antagonist, did not reverse the midazolamrelaxation. Several in vitro studies $2,4,16$ have also shown that the relaxation is not mediated through central benzodiazepine receptors because it is not reversed by flumazenil. Raeburn $e t a l .{ }^{16}$ found peripheral benzodiazepine binding sites in airway smooth muscle by radioligand $\left(\left[{ }^{3} \mathrm{H}\right] \mathrm{Ro5}-4684\right)$ and showed that Ro5-4684, a peripheral benzodiazepine agonist, produces spasmolytic effect on airway smooth muscle. However, they also showed that midazolam did not displace $\left[{ }^{3} \mathrm{H}\right] \mathrm{Ro} 5$ 4684 bound to benzodiazepine binding sites in airway smooth muscle, and that PKll195, peripheral benzodiazepine receptor antagonist could not reverse midazolam-induced spasmolytic effect. Other investigators ${ }^{2,4}$ have observed no effect of PKI1195 on midazolam relaxation. Therefore, it is unlikely that midazolam produces spasmolytic effects via central or peripheral benzodiazepine receptor activation.

Yoshimura $e t$ al. ${ }^{4}$ found that midazolam relaxed $\mathrm{K}^{+}-$ and carbachol-induced contraction of airway smooth muscle in accordance with a decrease in intracellular calcium by inhibition of the influx of extracellular $\mathrm{Ca}^{2+}$, and that central and peripheral benzodiazepine antagonist could not reverse the relaxation. Therefore, voltage sensitive $\mathrm{Ca}^{2+}$ channels may be involved in the mechanism.

Previously, we found that direct visualization using a superfine fibreoptic bronchoscope was more sensitive than dynamic pulmonary compliance and airway resistance in assessing airway calibre. ${ }^{10}$ However, one problem of the endoscopic technique was that when airway secretion, caused by histamine infusion, covered the tip of the bronchoscope the measurements cannot be continued. However, in the present study we did not experience this situation.

Gal and Suratt ${ }^{14}$ reported that tracheal intubation produced bronchoconstriction, but they did not show whether the irritant effect was tolerable 30 min after intubation. We previously assessed BCA and plasma concentrations of catecholamines at 30 and $60 \mathrm{~min}$ after bronchoscope placement.9 Neither BCA nor plasma concentrations of adrenaline or noradrenaline ( $<200 \mathrm{pg} \cdot \mathrm{ml}^{-1}$ ) changed. Therefore, we suggest that pentobarbitone anaesthesia, used in the present study, was sufficient to prevent the irritant effect.

In the present study flumazenil reversed the decrease in plasma adrenaline concentration produced by midazolam. Other investigators ${ }^{17,18}$ have also suggested that midazolam has sympatholytic effects that can be antagonized by flumazenil. Alpha sympathetic blockers $^{19}$ produce bronchodilation, and epidural block $^{20}$ has been reported to be effective in the treatment of asthma, although sympatholytic actions generally worsen bronchoconstriction. However, the dose of flumazenil that reversed midazolam sympatholysis did not antagonize the midazolam bronchodilating effect. Therefore, sympatholysis is unlikely to have been involved in the mechanism of bronchodilatation.

The present study suggests that midazolam is not an effective therapeutic agent in status asthmaticus because even in doses of $1.0 \mathrm{mg} \cdot \mathrm{kg}^{-1}$ midazolam reversed histamine-induced bronchoconstriction by only $40 \%$. However, it suggests that midazolam could be used safely as a sedative for such patients during mechanical ventilatory support without worsening the bronchoconstriction.

In conclusion, employing a direct visualization method using superfine fibreoptic bronchoscope, we found that midazolam has a spasmolytic effect on histamine-induced bronchoconstriction, an effect that was not reversed by flumazenil.

\section{Acknowledgments}

The authors wish to thank Emeritus Professor J.W.R. McIntyre (Edmonton, Canada) for his valuable comments.

\section{References}

1 Reves JG, Fragen RJ, Vinik HR, Greenblatt DJ. Midazolam: pharmacology and uses. Anesthesiology 1985; 62: 310-24.

2 Koga $Y$, Sato $S$, Sodeyama $N$, et al. Comparison of the relaxant effects of diazepam, flunitrazepam and midazolam on airway smooth muscle. Br J Anaesth 1992; 69: 65-9.

3 Cheng EY, Mazzeo AJ, Bosnjak ZJ, Coon RL, Kampine $J P$. Direct relaxant effects of intravenous anesthetics on airway smooth muscle. Anesth Analg 1996; 83: 162-8.

4 Yoshimura $H$, Kai $T$, Nishimura J, Kobayashi $S$, Takabasbi S, Kanaide H. Effects of midazolam on intracellular $\mathrm{Ca}^{2+}$ and tension in airway smooth muscles. Anesthesiology 1995; 83: 1009-20.

5 Yager $D$, Shore $S$, Drazen JM. Airway luminal liquid. Sources and role as an amplifier of bronchoconstriction. Am Rev Respir Dis 1991; 143: S52-4.

6 Warner DO, Vettermann J, Brusasco V, Rehder $K$. Pulmonary resistance during halothane anesthesia is not determined only by airway caliber. Anesthesiology 1989; 70: 453-60.

7 Brown RH, Herold CJ, Hirshman CA, Zerhouni EA, Mitzner $W$. In vipo measurements of airway reactivity using high-resolution computed tomography. Am Rev Respir Dis 1991; 144: 208-12. 
8 Brown RH, Mitzner W, Zerhouni E, Hirshman CA.

Direct in pipo visualization of bronchodilation induced by inhalational anesthesia using high-resolution computed tomography. Anesthesiology 1993; 78: 295-300.

9 Hashimoto $Y$, Hirota $K$, Obtomo $N$, Ishibara $H$, Matsuki $A$. In pivo direct measurement of the bronchodilating effect of sevoflurane using a superfine fiberoptic bronchoscope: comparison with enflurane and halothane. J Cardiothorac Vasc Anesth 1996; 10: 213-6.

10 Otomo $N$, Hirota $K$, Sato $T$, Hashimoto $\Upsilon$, Ishibara $\mathrm{H}$. In vivo assessment of droperidol-induced bronchial relaxation in dogs using a superfine fibreoptic bronchoscope. Br J Anaesth 1997; 78: 579-82.

11 Otomo $N$, Hirota $K$, Hashimoto $Y$, et al. Measurement of bronchodilation using a superfine fibreoptic bronchoscope. Br J Anaesth 1997; 78: 583-5.

12 Mokuzen $H$, Sakai $T$, Kita $N$, et al. Anesthesia for dogs. In: Mokuzen H, et al (Eds.). Vetenary Anesthesia Handbook. (Japanese) Tokyo: Gakuso Ltd, 1976: 91-169.

13 Kudo $M$, Kudo $T$, Oyama $T$. The simultaneous determination of plasma concentration of norepinephrine, epinephrine and dopamine by gaschromatography-mass spectrometry. (Japanese) Masui 1984; 33: 1099-103.

14 Gal TJ, Suratt PM. Resistance to breathing in healthy subjects following endotracheal intubation under topical anesthesia. Anesth Analg 1980; 59: 270-4.

15 Tamaoki J, Graf PD, Nadel JA. Effect of $\gamma$-aminobutyric acid on neurally mediated contraction of guinea pig trachealis smooth muscle. J Pharmacol Exp Ther 1987; 243: 86-90.

16 Raeburn $D$, Miller LG, Summer WR. Peripheral type benzodiazepine receptor and airway smooth muscle relaxation. J Pharmacol Exp Ther 1988; 245: 557-62.

17 Marty J, Gauzit R, Lefevre P, et al. Effects of diazepam and midazolam on baroreflex control of heart rate and on sympathetic activity in humans. Anesth Analg 1986; 65: 113-9.

18 Niv $D$, Whitwam JG, Loh L. Depression of nociceptive sympathetic reflexes by the intrathecal administration of midazolam. Br J Anaesth 1983; 55: 541-7.

19 Barnes PJ, Wilson NM, Vickers $H$. Prazosin, an alpha ${ }_{1}^{-}$ adrenoceptor antagonist, partially inhibits exerciseinduced asthma. J Allergy Clin Immunol 1981; 68: 411-5.

20 Bromage PR. Diagnostic and therapeutic applications. In: Bromage PR (Ed.). Epidural Analgesia. Philadelphia: WB Saunders 1978: 638-43. 